\title{
MEDICAL PROBLEMS OF AFGHAN REFUGEES
}

\author{
by Dr. Sajjad Jan, Afghan Surgical Hospital. Peshawar, Pakistan
}

\section{Summary:}

This article about the most burning problem of the day, is not based on some scientific medical research work; rather it is an informative article in which the data has been collected from the various mobile health units of the Islamic Movement of Pakistan, working in Afghan Refugee camps, and in the Afghan Surgical Hospital.

\section{The Problem: Afghanistan, A Country Occupied Against Its Will.}

Afghanistan is a land of great people and of immense strategic importance. It occupies a vital position on the map of Asia Minor. Political changes within this little country can set out a wave of events in the neighboring and far-off countries. It appears that Afghanistan is pivotal strategically and geographically, not only to the Eurasian continent. but perhaps to the whole globe. It is this geographically significant position which has. since times immemorial. attracted every great power of its time to try and capture and hold this land. The British Imperialism at the time of its zenith, made every possible effort to annex Afghanistan and add it to its international territory. The British, however, failed badly in the face of courage and endurance and the endless spirit of sacrifices of the great Afghan peoples. With the decline and withdrawal of British and Western Imperialism the world over, the Russians moved into places of tactical importance in the void that was created. They. however, adopted an entirely diflerent strategy. The Russians never came out initially with an impression of open confrontation: rather, like wolves in sheep's clothing, they signed treatics of Iriendship. In Afghanistan they gave heavy linancial aid and extended the so-called cordial cooperation in the fields of education, economics, culture, and literature. Thus, the Russians managed to give the lalse impression of extreme sincerity and affiliation towards the people of Afghanistan, but later on they started exploiting all opportunities for the propagation of the Communist ideology:

Under the camouflage of technical enhancement. a large number of Afghan intellectuals were brainwashed in Russia and sent back to their homeland as Communist missionaries. In a short time they seemed to change the political thought and it was a remarkable suecess for the Russians, or so at least it appeared initially. But, in fact, this was an illusion because this never impressed the common man in Alghanistan.

Although the Afghans are very humble and friendly
DOI: http://dx.doi.org/10.5915/14-1-12126

in their day-to-day dealings, they are extremely sensitive and sentimental in their religious zeal of Islam. The perpetual propagation of the Communist ideology started irritating the people and they realized rightly, this as a danger to their DEEN. They saw in it an enemy of Islam and decided. according to their long-established traditions, to reject this new philosophy and throw it back to the other side of the Amou River. This was totally an unexpected response for those who had planned to uproot and subdue that country. Soviet Russia was disappointed and in a state of desperation and started committing blunders and decided to implement its designs by naked and brute force. In this way Kabul had to witness a series of consecutive "coup de tats" and revolutions which caused great chaos and anarchy in the social. cultural. religious, and political life of the Afghan people.

The sheer ruthlessness of the puppet Kabul Regime created an atmosphere of complete insecurity and the people reacted by anarchy. They had realized that if they did not put up a fight they would not find any way to retain their most favorite asset - ISLAM, All these elements coupled together forced the Russian invasion of Afghanistan. The Afghan people fought bravely for their sweet motherland. but greatly overpowered with superior technology and military might of a super power, many courageously gave their lives for their country. Others had to take refuge in Pakistan.

\section{The Refugees:}

At present there are about two-and-a-half million Afghan refugees in Pakistan and one million in Iran. All of them live in tented camps under the open sky with little protection from the atmospheric changes of temperature, wind, and rain. There is overcrowding in each camp and the people have to sleep on the ground which frequently becomes moistened and damp due to rains. They have to use minimally purified water of wells and handpumps and the facilities available for sanitation and disposal of excreta and waste products are minimal or non-existent. Every member of the medical profession can imagine the types of medical and public health problems that can arise in these situations. All such conditions are sufficient to cause widespread epidemics, as usually happens in refugee camps.

During the last three years, thanks to the kind ness of Allah (s.w.t.), of Afghan occupation. the Alghans have not faced even a single epidemic.

Keeping this political and social background of the 
problems in mind, we can understand the medical problems in Afghan refugees in a better way. They can broadly be classified into two groups:

1. Medical problems of Afghan refugees in camps.

2. Medical problems of Afghan Mujahedin (people in war zones).

\section{Medical Problems of Afghan Refugees in Camps:}

The majority of these problems are being faced by children, ladies, old and aged people because the young healthy people are fighting inside Afghanistan as Mujahedin. The data being presented below have been recorded by five different doctors working in five different mobile units. The diagnosis has been made on the basis of standardized clinical judgment only, laboratory facilities being meager. The record was obtained during the months of August through November. 1981.

\begin{tabular}{|c|c|c|}
\hline \multirow[t]{4}{*}{ Total Number of Patients } & Seen & 59.140 \\
\hline & Male Patients & $24.845(42.01 \%)$ \\
\hline & Female Patents & $14.260(24.01 \%)$ \\
\hline & Chuldren & $20.035(33.09 \%)$ \\
\hline
\end{tabular}

THE DATE OF IXDIVIDTAI DISE ASES IS AS FOH IOWS

\begin{tabular}{|c|c|c|c|}
\hline Nature of Sickness & Male & Female & Children \\
\hline 1. Diarthea dysentery & $10.02 \%$ & $9 \%$ & 20.045 \\
\hline 2. Worm infestations & $4.05 f_{i}$ & $4.05 \%$ & $10.06 \%$ \\
\hline 3. Other gastric problems & 11.08 年 & $9.07 \%$ & $6.02 \%$ \\
\hline 4. Malnutrition: Deficiencies & $3,00 \%$ & $5.09 \%$ & $2.00 \%$ \\
\hline 5. Resp: Infec: (Excl: T.B.) & $19,1 \%$ & $14.4 \%$ & $17.5 \%$ \\
\hline 6. Susp. Conf: T.B. & $2.3 \%$ & $5.0 \%$ & $0.7 \%$ \\
\hline 7. Fever (Excl: Malaria) & $5.6 \%$ & 5.55 & $8.7 \%$ \\
\hline 8. Susp: Conf:Malara & $4.3 \mathrm{C}$ & $6.19 i$ & $5.4 \%$ \\
\hline 9. Ear infections & $2.7 \%$ & $2.3 i$ & $4.3 \%$ \\
\hline 10. Eye Infections & $4.5 \%$ & $4.03 \%$ & $6.5 / 7$ \\
\hline 11. Nervous sys: Psych: illnesses & $3.9 c_{i}$ & 7.99 & 1,19 \\
\hline 12. Joint Bone disease & 11.29 & $9.8 \%$ & $0.9 \gamma_{\gamma}$ \\
\hline 13. Misc; Aches and Pains & $2.6 \% \mathrm{i}$ & $2.9 \rho_{i}$ & - \\
\hline 14. Measles & - & - & $0.6 \%$ \\
\hline
\end{tabular}

\section{Medical Problems in Afghan Mujahedin (People in War Zones):}

The problems faced by Afghan Mujahedin are almost all surgical in nature and one can find almost any type of war injury. Unfortunately, the Mujahedin lack the facilities of first-aid on the fronts and therefore, the majority of Mujahedin with severe abdominal, thoracic and head injuries, dic on the spot. Only those severe injuries occuring near the border succeed in entering Pakistan. The majority of injuries which we are receiving are those of the upper and lower limbs.

The Mujahedin are fighting a gorilla war which is going on mainly in the mountains and therefore they cannot use the normal roads and routes for the transportation of emergencies. They have to take their patients across the border, on the backs on donkeys, mules, horses, and sometimes even the backs of their fellow Mujahedin. Because of these primitive and insufficient means of transportation and the tortuous mountainous routes which the Mujahedin have to adopt, it takes quite a long time to transport these patients to any hospitals. In our Afghan Surgical Hospital we are receiving the patients usually after two to three weeks: sometimes even after one to two-and-ahalf to three weeks; and sometimes even after one to one-and-a-half months after sustaining the injury. Such patients usually bring with them very badly infected wounds. often foul-smelling, and filled with sloughs. (SEE PICTURES). We have also received a large number of patients suffering from infections of gas gangrene and tetanus.

Very fortunately, the Afghan people, in their native country, have been least exposed to the antibiotics because of the very poor medical facilities available there. This is proving very beneficial because the bacteria present in such wounds, are highly sensitive to all sorts of antibiotics and even the Penicillins are proving very effective.

The common injuries which these people get are as follows:

1. Bullet injuries and compound fractures of various bones. We have also received cases of bullet injuries of the abdomen with multiple perforations of the bowel and bullet injuries of the chest with haemopneumothorax and bronchial fistulac.

2. Bombardment injuries - the most common sufferers of these haphazard injuries are children and women.

3. Toy bomb injuries - small innocent children are the usual victims of these bombs which resemble small toys and are thrown over the villages by these inhuman Russians. These children usually become crippled for the rest of their lives.

4. Gas bomb injuries - injuries due to gas bombs have also been received in our hospital. Such patients get dry cough as a symptom and miliary shadows in their lungs. Occasionally they present with dermatological manifestations.

5. We have also received patients injured by "dum dum" bullets where the bullets enter the body and burst inside causing very severe damage and torture. These bullets have been banned by Geneva Convention.

6. Mine blast injuries - mine explosion below the feet is a very frequent type of injury and it has crippled a very large number of Afghan youngsters.

7. Miscellaneous injuries due to hand grenades, rocket launchers, and other weapons are very incapacitating and disfiguring. Germ and Napalm bombs have also been reported. 
We are dealing very successfully with all these injuries in the Afghan surgical Hospital which has been specifically established to serve the needs of Afghan Mujahedin and refugees. We are performing all kinds of orthopaedic operations and trauma surgery. etc. The hospitals are still far from being totally equipped.

\section{Conclusion:}

The Afghan Mujahedin and Refugees are a great people in turmoil. Their fight is not only for survival. their fight is a fight to save the spirit of Islam. You as fellow Muslims and Brothers can help them to victory by supporting them morally, politically. financially. and medically. Donate your time and services to their cause. Remember.
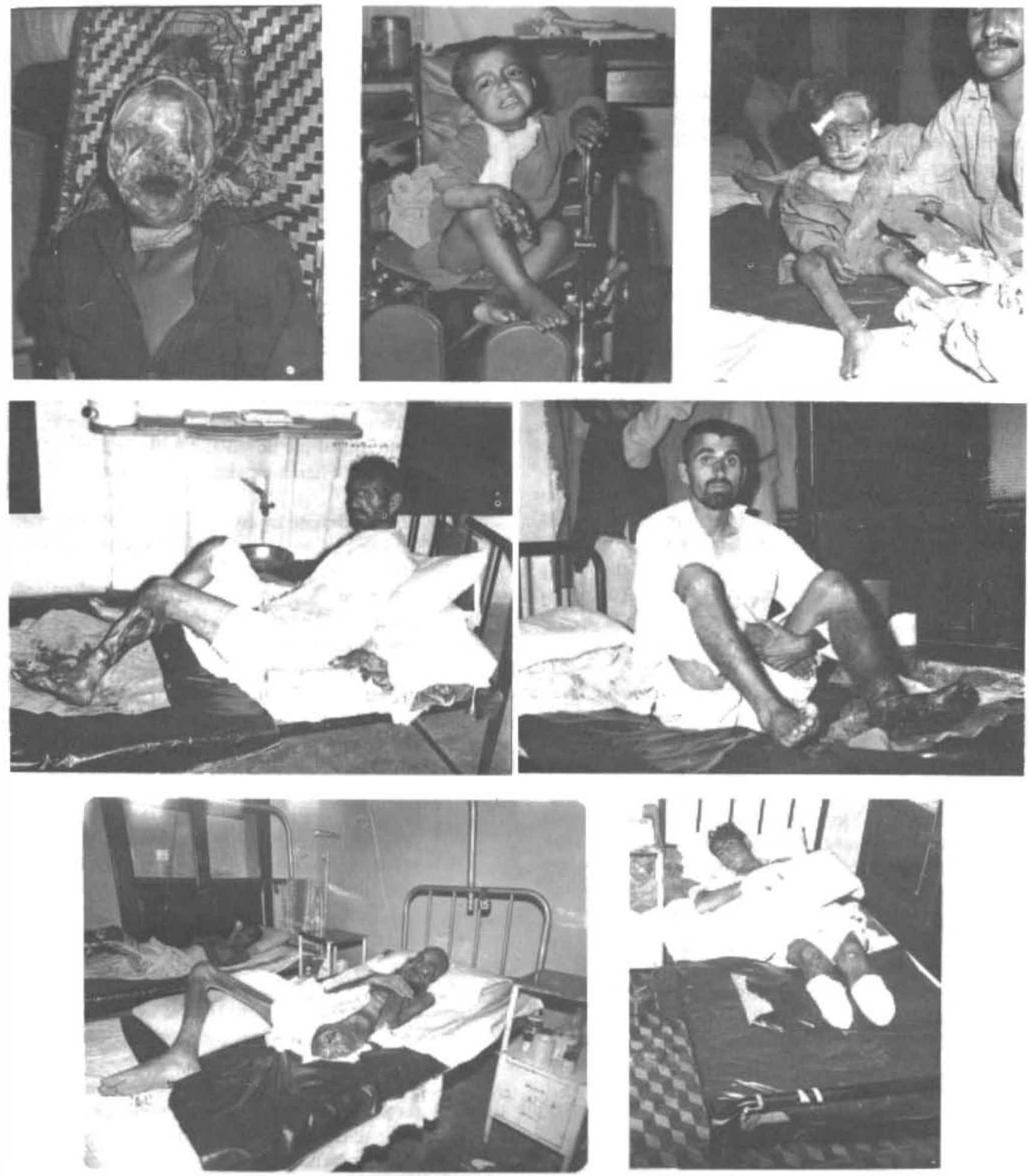